\title{
Effect of energy and dose of vitamin E selenium on improving the reproduction performance of Joper brood stock
}

\author{
Nining Haryuni ${ }^{1}$, Hartutik Hartutik ${ }^{2 *}$, Eko Widodo ${ }^{2}$, and Sri Wahjuningsih ${ }^{2}$ \\ ${ }^{1}$ Animal Science Doctoral Program, Faculty of Animal Science, University Brawijaya, Malang \\ 65145, East Java, Indonesia \\ ${ }^{2}$ Faculty of Animal Science, University Brawijaya, Malang 65145, East Java, Indonesia
}

\begin{abstract}
Production performance in Joper broodstock can be improved through increased feed energy and vitamin E-selenium supplementation. This study used 400 laying hens Isa Brown aged 35 weeks and 15 Sentul rooster aged 68 weeks. This study used a factorial completely randomized design with 2 factors, namely metabolic energy levels $(2,700$ and 2,800 $\mathrm{kcal} / \mathrm{kg})$ and vitamin E-selenium supplementation doses $(0,25,50,75$ and $100 \mathrm{ppm}$ ) where each treatment used 10 laying hens and repeated 4 times. The dose of selenium is $0.001 \mathrm{ppm} / \mathrm{mg}$ vitamin $\mathrm{E}$. The energy level has a very significant effect $(P<0.01)$ on (feed, protein and energy) intake and HDP. The dose level of vitamin E- selenium in feed had a very significant effect $(P<0.01)$ on HDP and significant $(P<0.05)$ on (feed, protein and energy) intake and FCR. The interaction between the two has a very significant effect $(P<0.01)$ on HDP. The average feed intake 113-115 $\mathrm{g} /$ day, protein intake $21.90-22.20 \mathrm{~g} /$ day and energy intake 308-317 $\mathrm{kcal} / \mathrm{bird}$. HDP $76.70-83.00 \%$. The conclusion of this study is that feed with metabolic energy of $2800 \mathrm{kcal} / \mathrm{kg}$ and vitamin E-selenium supplementation at a dose of $100 \mathrm{ppm}$ can improve the productivity of Joper broodstock.
\end{abstract}

\section{Introduction}

The global economy that has occurred in recent years has led to changes in lifestyle. In Indonesia, this global economy has made fast food made from chicken more popular and the spread of restaurants is getting wider. The national consumption of poultry meat in 2017 was 2,305,000 tons [1]. Poultry meat supplies $69 \%$ of the total national demand for meat, consisting of $55 \%$ broilers, $9 \%$ native chickens, $4 \%$ layer hens and $1 \%$ ducks [2]. In Indonesia, the poultry business is able to provide employment for 12 million people so that it has an important role in the national economy. One of the government policies made to improve the economy and realize food self-sufficiency is the development of livestock with local genetic sources [3].

\footnotetext{
* Corresponding author: hartutik@ub.ac.id
} 
Joper is a domestic chicken in Indonesia that produced from a cross between a laying chicken and a native rooster [4]. Joper demand has increased every year because it has a good immune system so that its maintenance system does not require antibiotics, the taste and texture of the meat is very distinctive [5]. In 2019, domestic chicken meat demand was only met by $30 \%$ [6]. The high demand for Joper meat is not balanced with Joper's population, so this business has great potential to be developed. The main problem with the limited supply of Joper is the lack of hatching eggs in the Joper breeding industry. According to [7] the broiler breeding industry is the main key in the successful development of the broiler industry. Reproductive factors have an important role in a broiler breeding industry. The reproductive performance of broodstock is a major factor in producing large amounts of DOC in a broiler breeding industry. The role of the ovaries is a major factor in reproduction and other supporting factors such as parent genetics, feed, age, environment and other factors. The same opinion was stated by [8] that reproductive performance determines the success of the broiler breeding industry and to maximize reproductive performance it is important to minimize the triggers of metabolic stress.

The limited supply of Joper DOC can be overcome by improving the reproductive performance of existing broodstock in the Joper breeding industry by supplementing with vitamin E-selenium and increasing feed energy. Vitamin $\mathrm{E}$ is an antioxidant that has an important role in regulating the metabolic system because it can protect cells from free radicals that damage cell work. Vitamin E works synergistically with selenium to protect tissue from oxidative damage and can be used to boost immunity. Optimum doses of vitamin $\mathrm{E}$ and selenium in feed can provide maximum protection during stress, maximum production and reproduction in hens [9].

Metabolic energy in the breeding industry will be utilized for maintenance requirements (basal metabolism, thermal regulation, immune response and activity), growth and egg production [10]. Energy balance plays an important role in the neuroendocrine system that affects the reproductive process [11]. Energy metabolism in laying hens produces glucose which is the main energy source for the brain [12]. The hypothalamus is a part of the brain that plays an important role in regulating the development of reproductive organs, follicular development, maturation and ovulation in laying hens [13]. Energy deficiency in industri broiler breeding causes a decrease in egg production due to disruption of hormone production by the hypothalamus. Energy will be stored in the form of body fat mass when maintenance requirements are fulfilled. Body fat mass has an important role in metabolism including as a precursor in the synthesis of reproductive hormones [14], to maximize the absorption of vitamin E-selenium and egg yolk lippoprotein synthesis [15]. Lippoprotein synthesis in broiler breeding is higher than that of laying hens for egg consumption purposes. The need for fat in broiler breeders is higher than that of laying hens because the lippoprotein in egg yolk is a source of nutrition for embryonic development. The combination of vitamin E-selenium supplementation and metabolic energy in feed is expected to improve the reproductive performance of Joper breedstock.

\section{Materials and methods}

\subsection{Experiemental design and feed}

This research is a biological experiment of feed treatment on Joper broodstock for 60 days. This study used a factorial completely randomized design method with 2 treatment factors. The treatment factors used in this study were 2 levels of metabolic energy (V) (2700 and $2800 \mathrm{kcal} / \mathrm{kg}$ ) and 5 doses of vitamin E-selenium (E) $(0,25,50,75$ and $100 \mathrm{ppm})$. The repetition of each treatment in this study was 4 times and in each treatment 10 laying hens 
were used. The number of chickens used in this study were 400 laying hen strain Isa Brown aged 35 weeks and 15 Sentul rooster aged 68 weeks. The Breedstock Jopers were placed in individual cages with a cage length of $50 \times 40 \times 30 \mathrm{~cm}$ and a front cage height of $37 \mathrm{~cm}$. Sentul rooster is placed in individual cages and separate from laying hens. Sentul rooster cage size is $70 \times 50 \times 100 \mathrm{~cm}$. The dose of selenium is $0.001 \mathrm{ppm} / \mathrm{mg}$ vitamin E. The frequency of feeding in this study was 2 times a day with $40 \%$ given at 6 am and $60 \%$ at $2 \mathrm{pm}$ and drinking water was given ad libitum.

\subsection{Semen collection and artificial insemination}

Semen was collected using the massage method. Before doing the massage, the abdominal area to the cloaca was cleaned using a tissue that had been sprayed with $70 \%$ alcohol. The massage is done by pressing gently from the abdomen to the cloaca and is stopped when the male begins to lift his tail and then the semen is ready to be collected using a scale tube. Semen collection was carried out half an hour before the artificial insemination activity. Laying hens were inseminated every 4 days with a dose of $0.20 \mathrm{ml}$ of semen per chicken. Total insemination for 2 months during the study was 15 times. Artificial insemination in this study used the method. The intravaginal method is the insemination method by inserting semen into the chicken's vagina with a depth of 2-4 cm. Artificial insemination (AI) was applied at $4 \mathrm{pm}$ to avoid damage to the eggs in the uterus.

\subsection{Parameters measure}

Feed treatment with a combination of metabolic energy and dose of vitamin E-selenium supplementation was given to Joper broodstock 2 times a day and inseminated every 4 days and then its productivity is observed. The productivity parameters observed in this study were feed intake, protein intake, energy intake, hen day production (HDP), egg weight, feed conversion ratio (FCR) and mortality. Feed intake was measured by subtracting the feed given to laying hens with the rest of the feed being weighed the next day. Protein and energy intake is calculated by multiplying feed intake by the protein or energy content in the feed. Feed intake, protein intake and energy intake Feed intake, protein intake and energy intake are recorded daily and averaged for weekly data. HDP, egg weight and FCR were measured by collecting daily data and then weekly averaged. FCR was measured by calculating the total daily feed consumption divided by the total weight of eggs produced each day and then calculating the average for each week. The health of Joper brooders was observed every day and recorded if any died to determine mortality and used for FCR calculations.

\subsection{Data analysis}

All data obtained during the study were collected and analyzed using analysis of variance (ANOVA). Analysis of variance used a Factorial Completely Randomized Design (CRD) with 2 treatment factors and was repeated 4 times. Statistical analysis is continued with Duncan's test if the results obtained provide significant or very significant differences in influence. 
Table 1. Composition and nutrient content of experimental diets

\begin{tabular}{|c|c|c|}
\hline \multirow{2}{*}{ Ingredients } & \multicolumn{2}{|c|}{ Treatment } \\
\hline & E1 & $\mathbf{E 2}$ \\
\hline Corn $(\%)$ & 48.90 & 51.30 \\
\hline Soy bean meal, $45 \%$ CP (\%) & 21.60 & 22.10 \\
\hline Rice bran (\%) & 12.20 & 8.40 \\
\hline Meat bone meal (\%) & 8.00 & 8.00 \\
\hline Stone grit (\%) & 5.00 & 5.00 \\
\hline Stone powder $(\%)$ & 3.30 & 3.10 \\
\hline Fat powder $(\%)$ & 0.00 & 1.11 \\
\hline Complete premix (\%) & 0.50 & 0.50 \\
\hline Monocalcium phospate (\%) & 0.30 & 0.30 \\
\hline Salt (\%) & 0.10 & 0.10 \\
\hline Sodium bicarbonat (\%) & 0.07 & 0.07 \\
\hline \multicolumn{3}{|c|}{ Calculated Composition } \\
\hline Metabolic energy (kcal/kg) & 2,701 & 2,800 \\
\hline Crude protein $(\%)$ & 19.00 & 19.00 \\
\hline Crude fat $(\%)$ & 4.40 & 5.06 \\
\hline Crude fiber (\%) & 3.60 & 3.24 \\
\hline Lysine (\%) & 0.96 & 0.96 \\
\hline Metionin (\%) & 0.50 & 0.50 \\
\hline Methionine + cystine $(\%)$ & 0.87 & 0.87 \\
\hline Threonine (\%) & 0.75 & 0.75 \\
\hline Triptopane (\%) & 0.22 & 0.22 \\
\hline Calsium (\%) & 3.99 & 3.91 \\
\hline Total phosphorus (\%) & 0.83 & 0.78 \\
\hline Phospor avail (\%) & 0.50 & 0.49 \\
\hline Sodium (\%) & 0.13 & 0.13 \\
\hline
\end{tabular}




\begin{tabular}{|l|c|c|}
\hline Chloride (\%) & 0.15 & 0.15 \\
\hline
\end{tabular}

Calculation of feed composition using Brill Formulation software

\section{Results and discussion}

Based on research on improving the performance of Joper broodstock production, data on productivity of Joper brooders with increased metabolic energy, dose of vitamin Eselenium supplementation, and interaction between metabolic energy level and dose of vitamin E-selenium supplementation were shown in Table 2.

Different superscripts in the same column showed that the energy level had a very significant effect $(P<0.01)$ on the performance of laying hens; dose of vitamin E-selenium gave a very significant effect $(P<0.01)$ on HDP and significantly $(P<0.05)$ on feed intake, protein intake, energy intake, FCR; the interaction between energy level and dose of vitamin E-selenium gave a very significant effect $(P<0.01)$ on HDP.

\subsection{Feed intake}

The results of this study showed that there was no interaction between metabolic energy levels and the dose of vitamin E-selenium supplementation in the feed on feed consumption. Feed consumption was influenced by a single factor of metabolic energy level and vitamin E-selenium supplementation. Statistical analysis showed that a single factor of energy level had a very significant effect $(P<0.01)$ on feed consumption, while a single factor of vitamin E-selenium supplementation had a significant effect $(P<0.05)$ on feed consumption. The feed intake in this study ranged from $113-115 \mathrm{~g} / \mathrm{bird}$ according to the Isa Brown Commercial Management Guide (2014) $113 \mathrm{~g} / \mathrm{bird}$ at 35 weeks of age.

Energy is one of the limiting factors for feed intake. The central nervous system (CNS) in poultry has an important role in regulating energy utilization and reproduction. The hypothalamus is a part of the CNS that has a major role in regulating feed intake and energy expenditure [11]. Homeostatic regulation of energy in the hypothalamus is in the form of regulating hunger. Hunger is an integration of metabolic signals that indicate energy status when the body needs energy intake and is responded to in the form of an appropriate appetite [16]. Appetite encourages the behavior of laying hens to increase feed intake so that higher feed energy will reduce appetite because energy requirements have been fulfilled. [17] and [18] reported a decrease of $3.46-18.50 \%$ of feed intake when the feed was increased by about $100-310 \mathrm{kcal} / \mathrm{kg}$ of metabolic energy.

Vitamin E-selenium has a very important role in the Joper breeder industry. Vitamin E plays a role in fat metabolism which is used as a precursor for reproductive hormones, functions as an enzyme to increase metabolism and works synergistically with selenium to protect oxidative damage to cells, especially in the process of embryonic development. Increasing the concentration of vitamin E-selenium in the feed will be transferred to the egg yolk and will increase hatchability [19]. Supplementation of vitamin E-selenium in the diet of Joper breeders has an impact on optimal lipid metabolism and a healthier digestive system so that it can increase feed efficiency and decrease feed intake. 
Table 2. Effect of metabolic energy level on productivity of Joper broodstock

\begin{tabular}{|c|c|c|c|c|c|c|c|}
\hline \multirow[b]{2}{*}{ Treatment } & \multicolumn{7}{|c|}{ Variable } \\
\hline & $\begin{array}{c}\text { Feed } \\
\text { Intake } \\
\text { (g/bird) }\end{array}$ & $\begin{array}{c}\text { Protein } \\
\text { Intake } \\
\text { (g/bird) }\end{array}$ & $\begin{array}{c}\text { Energy } \\
\text { Intake } \\
\text { (kcal/bird) }\end{array}$ & $\begin{array}{l}\text { HDP } \\
(\%)\end{array}$ & $\begin{array}{c}\text { Egg } \\
\text { Weight } \\
\text { (g) }\end{array}$ & FCR & $\begin{array}{c}\text { Mortality } \\
\text { (\%) }\end{array}$ \\
\hline \multicolumn{8}{|c|}{ Metabolic energy level } \\
\hline E1 & $114.00^{\mathrm{b}}$ & $22.20^{\mathrm{b}}$ & $309.00^{\mathrm{a}}$ & $78.60^{\mathrm{a}}$ & $62.20^{\mathrm{a}}$ & $2.42^{\mathrm{b}}$ & 0.01 \\
\hline E2 & $113.00^{\mathrm{a}}$ & $21.90^{\mathrm{a}}$ & $318.00^{\mathrm{b}}$ & $80.70^{\mathrm{b}}$ & $64.00^{\mathrm{b}}$ & $2.28^{\mathrm{a}}$ & 0.00 \\
\hline \multicolumn{8}{|c|}{ Suplementasion vitamin E-selenium } \\
\hline V0 & $115.00^{\mathrm{b}}$ & $22.12^{\mathrm{b}}$ & $314.00^{\mathrm{b}}$ & $76.70^{\mathrm{a}}$ & 62.80 & $2.41^{\mathrm{b}}$ & 0.02 \\
\hline V1 & $114.00^{\mathrm{a}}$ & $22.10^{\mathrm{a}}$ & $313.00^{\mathrm{a}}$ & $79.20^{\mathrm{ab}}$ & 63.20 & $2.38^{\mathrm{a}}$ & 0.02 \\
\hline V2 & $114.00^{\mathrm{a}}$ & $22.10^{\mathrm{a}}$ & $313.00^{\mathrm{a}}$ & $79.00^{\mathrm{a}}$ & 63.10 & $2.39^{\mathrm{ab}}$ & 0.00 \\
\hline V3 & $114.00^{\mathrm{a}}$ & $22.11^{\mathrm{ab}}$ & $313.00^{\mathrm{a}}$ & $80.60^{\mathrm{b}}$ & 63.20 & $2.30^{\mathrm{a}}$ & 0.00 \\
\hline V4 & $114.00^{\mathrm{a}}$ & $22.10^{\mathrm{a}}$ & $313.00^{\mathrm{a}}$ & $82.70^{\mathrm{c}}$ & 63.30 & $2.28^{\mathrm{a}}$ & 0.00 \\
\hline \multicolumn{8}{|c|}{ Interaction of vitamin E-selenium supplementation and metabolic energy } \\
\hline V1V0 & 114.50 & 22.20 & 309.10 & $77.40^{\mathrm{a}}$ & 61.70 & 2.46 & 0.04 \\
\hline V1V1 & 114.30 & 22.20 & 308.50 & $77.60^{\mathrm{a}}$ & 62.30 & 2.45 & 0.04 \\
\hline E1V2 & 114.20 & 22.20 & 308.20 & $77.30^{\mathrm{a}}$ & 62.30 & 2.48 & 0.00 \\
\hline E1V3 & 114.30 & 22.20 & 308.60 & $78.30^{\mathrm{a}}$ & 62.40 & 2.38 & 0.00 \\
\hline E1V4 & 114.30 & 22.20 & 308.60 & $82.60^{\mathrm{ab}}$ & 62.50 & 2.34 & 0.00 \\
\hline E2V0 & 113.40 & 22.00 & 317.60 & $76.00^{\mathrm{a}}$ & 63.80 & 2.35 & 0.00 \\
\hline E2V1 & 113.40 & 22.00 & 317.60 & $80.70^{\mathrm{a}}$ & 64.20 & 2.31 & 0.00 \\
\hline E2V2 & 113.40 & 22.00 & 317.40 & $80.70^{\mathrm{a}}$ & 63.90 & 2.30 & 0.00 \\
\hline E2V3 & 113.40 & 22.00 & 317.60 & $83.00^{\mathrm{b}}$ & 64.10 & 2.22 & 0.00 \\
\hline E2V4 & 113.40 & 22.00 & 317.50 & $82.90^{\mathrm{b}}$ & 64.10 & 2.22 & 0.00 \\
\hline
\end{tabular}

\subsection{Protein intake}

Protein intake is influenced by the energy and protein content in feed. Protein intake is calculated by multiplying the amount of feed intake by the protein content of the feed [20]. Protein consumption in Joper broodstock serves to meet the protein needs needed by the body to carry out metabolic processes. When the Joper broodstock lacks energy, one of the nutrients that can be converted into energy other than fat is protein. Statistical analysis showed that there was no interaction between the energy level factor and the dose of vitamin E-selenium supplementation on protein consumption, but protein consumption was 
significantly $(P<0.01)$ influenced by energy level and significantly $(P<0.05)$ by supplementation dose of vitamin E-selenium. The single factor of energy level has a more dominant influence than the dose of vitamin E-selenium supplementation. The average protein intake obtained ranged from $21.90-22.20 \mathrm{~g} / \mathrm{bird}$.

Energy level has a dominant influence on protein consumption than vitamin E-selenium supplementation dose because energy is a limiting factor in feed consumption. Protein consumption is strongly influenced by feed consumption because in this study all treatment feeds had the same protein content but different energy. This causes protein consumption to decrease when feed consumption decreases. The same opinion was reported by [21] who stated that metabolic energy in feed is positively correlated with feed intake and protein consumption. Feeds with high energy content will reduce feed consumption and protein consumption.

\subsection{Energy intake}

Energy level had a very significant effect $(P<0.01)$ and vitamin E-selenium level had a significant effect $(P<0.05)$ on energymetabolism intake, but the interaction between the two gave no significant effect $(P>0.05)$. High energy intake is obtained in E2 treatment. E2 is a treatment with a higher metabolic energy than E1. This shows that energy consumption is directly proportional to the amount of energy in the feed so that the energy intake also increases along with the increased energy in the feed. The energy intake obtained in this study ranged from $308-318 \mathrm{kcal} /$ bird and was lower than the results reported by [22] of 326-332kcal/bird in laying hens of the Lohman brown strain.

Table 2 shows that vitamin E-selenium supplementation has an impact on lower energy intake. Metabolic energy intake in broiler breeder hens is utilized for maintenance (HP), ME retained in the body and egg mass produced. Broiler breeder hens require a higher energy intake than laying hens so that surplus energy is stored as body fat mass and utilized for the synthesis of lipoproteins in egg yolks [10]. Hatching eggs require high lippoprotein to maximize embryo development during hatching.

\subsection{Hen Day Production (HDP)}

Energy level, vitamin E-selenium dose and the interaction between them had a very significant effect $(P<0.01)$ on HDP. The average HDP obtained in this study ranged from $76.70-83.00 \%$ and was lower than the [23] of $93.30 \%$ at 35 weeks of age. This is due to differences in the purpose of rearing which in the [23] is a guide for laying hens, not broiler breeders. The HDP of broiler breeders is lower than that of laying hens due to high metabolic stress. [22] reported that egg production increased with an increase in feed energy from $2,400 \mathrm{kcal} / \mathrm{kg}$ to $2800 \mathrm{kcal} / \mathrm{kg}$. The same thing was reported by [24] that an increase in metabolic energy from $874 \mathrm{kj}$ to $1,034 \mathrm{kj}$ can increase egg production. [25] also reported that the most important factors that must be considered in hens' feed are energy and protein.

Evaluation of reproductive performance in broiler breeders is prioritized on fertility, hatchability and quality of day old chick (DOC) produced. Hatchability related with lipoprotein in egg yolk which is used as the main source of nutrition in embryonic development. High lipid requirements cause high lipid metabolism. The oxidation reaction of fatty acids will release oxygen which is called reactive oxygen species (ROS). The increased amount of Ros can cause oxidative stress, namely an imbalance between oxidants and antioxidants. Vitamins $\mathrm{E}$ is a natural antioxidants that play a role in the breakdown of fat chains and prevent cell damage caused by free radicals. Vitamin E-selenium supplementation can reduce oxidative stress so that egg production can increase [26]. 
Energy in feed is the main factor in the source of body fat mass. Body fat mass will then be used in the process of forming reproductive hormones [10]. Increased energy in broiler breeder feed will improve egg production, egg weight, egg white and yolk weight, reduce feed intake and reduce FCR [13].

The interaction between energy levels and vitamin E-selenium supplementation is very effective in controlling stressors that trigger metabolic stress in broodstock. Vitamin $\mathrm{E}$ is a natural antioxidant that can counteract free radicals which are stressors in Joper breeders.

\subsection{Egg Weight}

Statistical analysis showed that egg weight was significantly affected $(P<0.01)$ by a single factor of metabolic energy level in the feed. The average egg weight in this study ranged from 61.70 to $64.10 \mathrm{~g} / \mathrm{egg}$. This average egg weight is in accordance with the [23] which states that the standard weight of chicken eggs at 35 weeks is $62.80 \mathrm{~g}$.

Metabolic energy in feed plays an important role in egg formation. High energy intake will result in large egg and yolk weight. This is because $75 \%$ of the yolk component comes from feed energy. [25] and [13] reported that an increase in metabolic energy in feed can increase egg weight, egg white and yolk weight. [4] reported that the dominant factor influencing egg weight is the nutrients in the feed, especially energy and protein. The main constituent of an egg is $73.7 \%$ water; Protein $12.9 \% ; 11.2 \%$ fat and $0.9 \%$ carbohydrates.

\subsection{Feed Conversion Ratio (FCR)}

The calculation of the FCR value is used to describe the effectiveness of the use of nutrients in producing eggs. FCR can be used as a parameter in measuring the efficiency of livestock business. FCR is a parameter in estimating the profit rate of livestock business. Increased energy in broiler breeder feed will improve FCR [13]. Increased energy in feed and vitamin E-selenium supplementation can reduce FCR because it can reduce feed consumption, increase egg production and increase egg weight.

Feed Conversion Ratio (FCR) was significantly $(P<0.01)$ influenced by energy level and significantly $(P<0.05)$ influenced by vitamin E-selenium dose, but there was no interaction between the two factors. The average FCR obtained in this study ranged from 2.22-2.48. The FCR obtained is higher than the [23] at the age of 35 weeks of 1.93 .

Metabolic stress in broiler breeders can cause a decrease in hypothalamic function due to cell damage and result in low egg production and quality [8]. Vitamin $\mathrm{E}$ works synergistically with selenium to protect cells from damage that interferes with metabolism. Vitamin E-selenium supplementation will have an impact on better health and high egg production [26]. High energy feed can be used to meet the high energy requirements of broiler breeders. Energy homeostasis in the hypothalamus affects the optimal work of the hypothalamus in regulating the body's metabolism so that egg production becomes optimal. Increasing feed energy will improve feed utilization efficiency so that feed intake decreases $[11,13]$.

\subsection{Mortality}

Energy levels, vitamin E-selenium levels and the interaction between the two factors had no significant effect $(P>0.05)$ on mortality. The mortality rate in this study ranged from $0.00-0.02 \%$. This result is lower than the standard [23] of $0.10 \%$ at the age of 35 . The low mortality indicates that the maintenance system in this study is good and meets the requirements. 
Necropsy on the carcass of the dead Joper broodstock found a swollen heart and ruptured blood vessels. This is probably caused by heat stress. Heat stress is the impact of oxidative stress that occurs when Joper brooders produce higher lippoproteins than laying hens in general. Oxidative stress in Joper broodstock encourages the pituitary to form the hormone cortisone. This hormone is a glucocorticoid group that plays a role in carbohydrate metabolism including the processes of glycolysis, gluconeogenesis and lipolysis. Corticosterone levels in the blood increase when oxidative stress occurs which triggers a higher rate of carbohydrate metabolism. This causes the body of the Joper broodstock to become hotter and under conditions of unbalanced energy supply and metabolic rate, it will disrupt all regulatory systems in the body.

\section{Conclusion}

The conclusion of this study is that the combination of energy levels and dose of vitamin Eselenium in feed can improve the performance of Joper broodstock. The best results were obtained metabolic energy at $2800 \mathrm{kcal} / \mathrm{kg}$ and a dose of vitamin E-Selenium at $100 \mathrm{ppm}$.

First of all. I thank Allah for His great love for me, giving me patience and strength to complete my doctoral studies. Second. I thank the Ministry of Education and Culture for the BPPDN scholarship for funding my doctoral studies. Third. I am very grateful to my supervisor Dr. Eko Widodo for all his knowledge, advice and evaluation on my paper.

\section{References}

1. V. Tenrisanna, S. N. Kasim, IOP Conf. Ser. Earth Environ. Sci, 492, 1-7 (2020)

2. C. Sumantri, I. Khaerunnisa, A. Gunawan, IOP Conf. Ser. Earth Environ. Sci, 492, 1$13(2020)$

3. C. Ferlito, H. Respatiadi, Policy reform on poultry industry in Indonesia: center for indonesian policy studies, (Jakarta, Indonesia, 2019)

4. Muharlien, I. W. Nursita, V. M. Pangestu, IOP Conf. Ser. Earth Environ. Sci, 478, 1-7 (2020)

5. J. K. L. Kalangi, A. K. Rintjap, J. Lainawa, IOP Conf. Ser. Earth Environ. Sci, 478 (2019)

6. T. Immawan, A. Puruhita, W. N. Cahyo, IOP Conf. Ser.: Mater. Sci. Eng, 598, 1-6 (2019)

7. J. Wang, C. Zhang, S. Zhao, X. Ding, S. Bai, Q. Zeng, K. Zhang, Y. Zhuo, S. Xu, X. Mao, H. Peng, Z. Shan, Poult. Sci. J., 100, 1-7 (2021)

8. M. J. Zuidhof, M. V. Fedorak, C.A. Ouellette, I. I. Wenger, Poultry Science, 96, 22542263 (2017)

9. P. F. Surai, I. I. Kochish, Poultry Science, 98, 4231-4239 (2019)

10. S. H. Hadinia, P. R. O. Carneiro, D. R. Korver, M. J. Zuidhof, Poultry Science, 98, 6721-6732 (2019)

11. S. H. Hadinia, P.R.O. Carneiro, C. J. Fitzsimmons, G. Y. Bedecarrats, M. J. Zuidhof, Poultry Science, 99, 2215-2229 (2020)

12. N. Mellouk, C. Ramé, A. Barbe, J. Grandhaye, P. Froment, J. Dupont, Int. J. Endocrinol, 2018, 1-19 (2018)

13. M. Liu, Y. Lu, P. Gao, X. Xie, D. Li, D. Yu, M. Yu, Poultry Science, 99, 2196-2202 (2020)

14. J. Heijmans, M. Duijster, W. J. J. Gerrits, B. Kemp, R. P. K.Wakkel, H. V. D. Brandz, Poultry Science, 100, 101131 (2021) 
15. J. Ren, W. Tian, K. Jiang, Z. Wang, D. Wang, Z. Li, F. Yan, Y. Wang, Y. Tian, K. Ou, H. Wang, X. Kang, H. Li, X. Liu, BMC Genom, 22, 1-14 (2021)

16. J. J. Lees, C. Lindholm, P. Batakis, M. Busscher, J. Altimiras, Scientific Reports 7, 111 (2017)

17. Z. Bu, P. Xie, S.Y. Fu, H.B. Tong, X. Dai, J Appl Poult Res, 24, 371-379 (2015)

18. Y. Ding, X. Bu, N. Zhang, L. Li, X. Zou, Journal of Animal Nutrition, Chinese Association of Animal Science and Veterinary Medicine, 2, 93-98 (2016)

19. J. I. M. Fernandes, H. L. F. Bordignon, K. Prokoski, R. C. Kosmann, E. Vanroo, A. E. Murakami, Med. Vet. Zootec, 70, 983-992 (2018)

20. L. D. Mahfudz, U. Atmomarsono, D. Sunarti, E. Suprijatna, T. A. Sarjana, Egypt. Poult. Sci. J, 31, 491-500 (2011)

21. A. Alderey, A, H. R. Samak, A. M. E. Nasr, H. A. Abu khashaba, J.Animal and Poultry Prod, Mansoura Univ, 8, 435 - 442 (2017)

22. F. Li, L. M. Zhang, X. H. Wu, C. Y. Li, X. J. Yang, Y. Dong, A. Lemme, J. C. Han, J. H. Yao, J Appl Poult Res, 22, 36-46 (2013)

23. Isa Brown Management Guide, (Kitchener, Canada, 2014)

24. A. M. Kingori, A. M. Wachira, J. K. Tuitoek, Int. J. Poult. Sci, 13, 151-155 (2014)

25. J. Nashr, J. Agric. Sci, 49, 53-57 (2015)

26. Y. N. Min, Z. Y. Niu, T. T. Sun, Z. P. Wang, P. X. Jiao, B. B. Zi, P. P. Chen, D. L. Tian, F. Z. Liu, Poultry Science, 97, 1238-1244 (2018) 